\title{
Effects of Volcanism on the Glaciers of Mount St. Helens
}

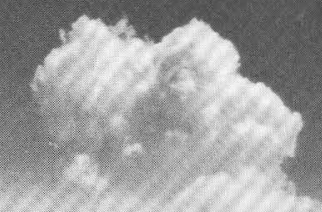




\section{METRIC CONVERSION FACTORS}

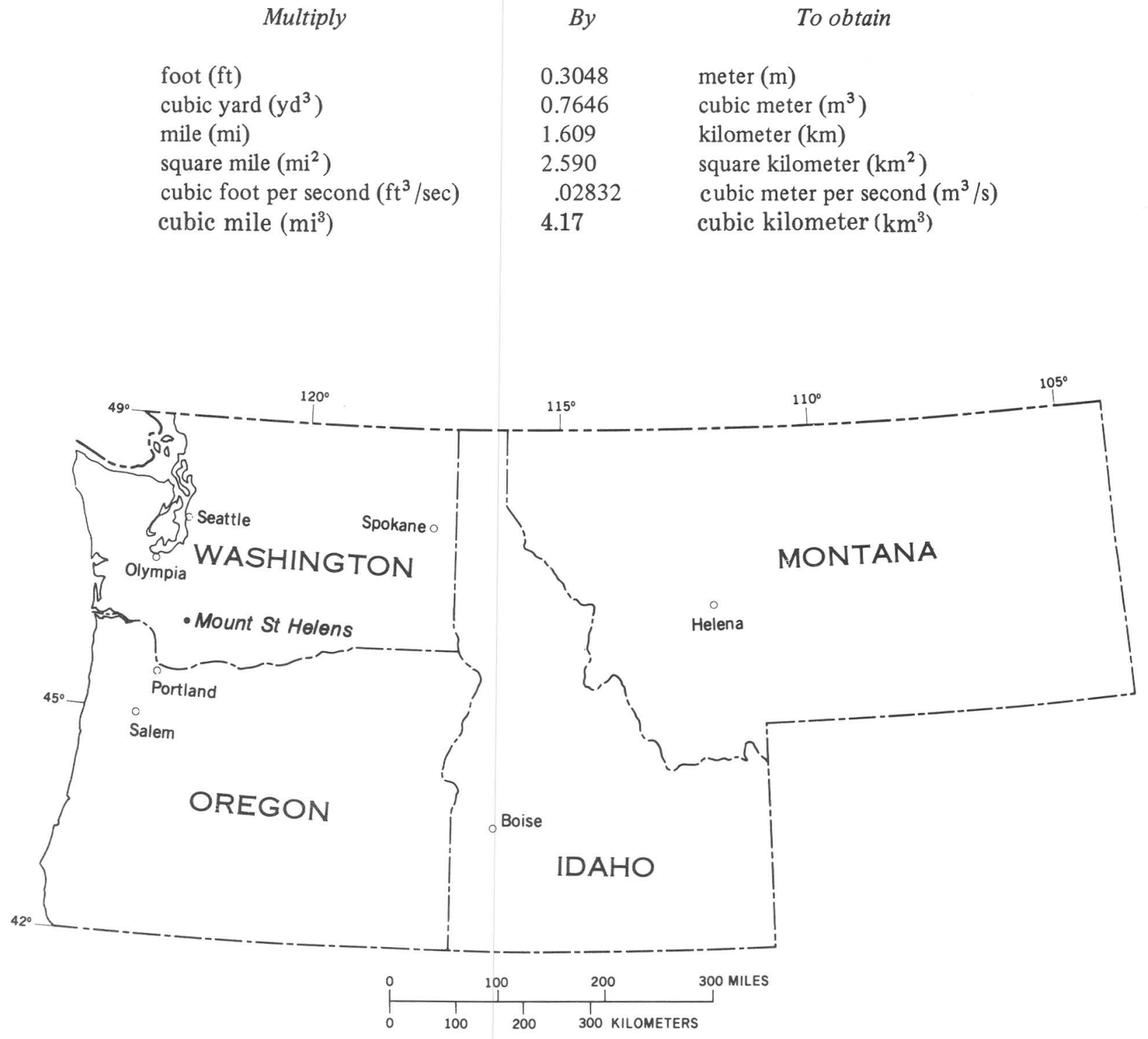

COVER: North Fork Toutle River, June 30, 1980. Volcanic mud flow breccia and debris from the May 18, 1980 eruption of Mount St. Helens (in upper right) are as much as several hundred feet thick in the reach shown. Photograph by Austin Post, U.S. Geological Survey. 


\section{Effects of Volcanism on the Glaciers of Mount St. Helens}

By Melinda M. Brugman and Austin Post

Hydrologic Effects of the Eruptions of

Mount St. Helens, Washington, 1980

GEOLOGICAL SURVEY CIRCULAR 850-D 
United States Department of the Interior

JAMES G. WATT, Secretary

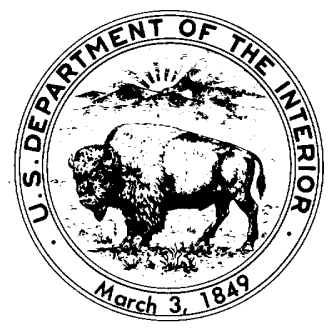

\section{Geological Survey}

Dallas L. Peck, Director

First printing 1981

Second printing 1983 


\section{FOREWORD}

On May 18, 1980, after more than a month of earthquakes and eruptions, Mount St. Helens, in southwestern Washington, exploded in a volcanic eruption more violent than any in the conterminous United States during the 20th century. A lateral blast of hot gas and rock particles devastated an area of about 150 square miles on the northern side of the mountain knocking down trees to a distance of 15 miles. Several minutes later, a giant ash cloud rose to about 60,000 feet. Winds then carried the ash cloud across the United States, with heavy fallout and deposition in eastern Washington and parts of Idaho and Montana. Earlier, smaller eruptions deposited ash in western Washington and parts of Oregon and Canada.

The hydrologic effects of the May 18 eruption have been both widespread and intense. During the eruption, a massive debris avalanche moved down the north flank of the volcano depositing about 3 billion cubic yards of rock, ice, and other materials in the upper 17 miles of the North Fork Toutle River valley. The debris deposits are about 600 feet thick in the upper reaches of the valley. Following the avalanche, runoff from the melted glaciers and snow, and possible outflow from Spirit Lake, caused an extraordinary mudflow in the North Fork Toutle River. The mudflow shattered and uprooted thousands of trees, destroyed most of the local bridges, and deposited an estimated 25,000 acre-feet of sediment in the Cowlitz River channel. A considerable amount of additional sediment was conveyed through the lower Cowlitz into the Columbia River where it deposited and formed a shoal that blocked the shipping channel. Mudflows also occurred in the South Fork Toutle River and in tributaries on the east flank of Mount St. Helens which enter Swift Reservoir.

As part of a concerted Geological Survey effort to study the volcanic event and to identify potential hazards, Survey hydrologists have mounted an intensive program to document the hydrologic effects of the eruptions. The major initial hydrologic findings are reported in this circular series. Quick, useful assessment was made possible only because the Survey has long conducted extensive waterresources investigations in the affected areas of Washington, Oregon, and Idaho. Hence, there was a well-defined basis for identification and documentation of the types and magnitudes of hydrologic changes.

The Geological Survey Circular 850, "Hydrologic Effects of the Eruptions of Mount St. Helens, Washington, 1980," consists of individually published short chapters that emphasize data collection activities, field observations, and initial comparisons of pre- and post-eruption conditions. The series will cover hydrologic events occurring on May 18 in the Toutle and Cowlitz River; physical alteration of the Toutle River system; the chemical and physical quality of precipitation, streams, and lakes affected by volcanic ash fall; ash-leaching studies; and Mount St. Helens glaciers.

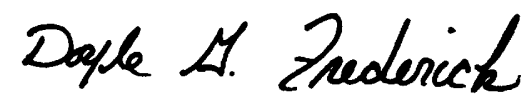

Doyle G. Frederick Acting Director 



\section{CONTENTS}

Page

Page

Abstract

Introduction

D1 Specific Effects of Volcanic Activity on Glaciers-Cont.

Background

1 May 19 to October 6

D6

Specific Effects of Volcanic Activity on Glaciers

1 Glacier Outburst Floods _...

March 20 to May 17

Discussion: Potential Hazards and Research

May 18

Opportunities

\section{ILLUSTRATIONS}

Figures 1-3. Maps of Mount St. Helens:

1. Before May 18, 1980, showing glaciers

Page

2. After May 18, 1980, showing remains of glaciers

3. Showing areas affected by blast

4-8. Photographs of:

4. Mount St. Helens from the northeast before the 1980 eruptive activity

5. Mount St. Helens from the northeast during period of deformation and minor eruptions preceding cataclysmic eruption of May 18, 1980---

6. Mount St. Helens from the northeast after the May 18, 1980, eruption--

7. Crater rim following the May 18,1980 , eruption, showing cross sections of glaciers

8. Glaciers on Mount St. Helens following the May 18, 1980, eruption.

D2

3

4

5

6

8

9

10

\section{TABLES}

TABLE 1. Glacier area, depth, and volume, before and after the May 18, 1980, eruption

2. Depths of glaciers on Mount St. Helens measured by radio-echo sounding 



\title{
EFFECTS OF VOLCANISM ON THE GLACIERS OF MOUNT ST. HELENS
}

\author{
By Melinda M. Brugman and Austin Post
}

\begin{abstract}
The cataclysmic eruption of Mount St. Helens May 18, 1980, removed $2.9 \mathrm{~km}^{2}$ (about $0.13 \mathrm{~km}^{3}$ ) of glacier snow and ice including a large part of Shoestring, Forsyth, Wishbone, Ape, Nelson, and all of Loowit and Leschi Glaciers. Minor eruptions and bulging of the volcano from March 27 to May 17 shattered glaciers which were on the deforming rock and deposited ash on other glaciers. Thick ash layers persisted after the May 18 eruption through the summer on most of the remaining snow and ice, and protected winter snow from melting on Swift and Dryer Glaciers. Melting and recrystalization of snow and ice surviving on Mount St. Helens could cause and lubricate mudflows and generate outburst floods. Study of glaciers that remain on this active volcano may assist in recognizing potential hazards on other volcanoes and lead to new contributions to knowledge of the transient response of glaciers to changes in mass balance or geometry.
\end{abstract}

\section{INTRODUCTION}

This article briefly summarizes the effects which the 1980 eruptive activity of Mount St. Helens had on the snow and ice masses on the volcano. The volcanic activity from March 20 through October 6,1980 , is divided into three periods, and topics such as glacial outburst floods, mudflows, and ash blanket effects are discussed. Areas, depths, and volumes of ice before and after May 18, 1980, are displayed in two tables, indicating the magnitude of the explosion which removed $2.6 \mathrm{~km}^{3}(99$ billion $\left.\mathrm{ft}^{3}\right)$ of the volcanic cone and about $0.1 \mathrm{~km}^{3}$ (3.5 billion $\mathrm{ft}^{3}$ ) of glacier snow and ice within minutes. Studies of the role of snow and ice in the damaging effects of the 1980 eruptions is essential for three major reasons: scientific understanding, predictions of the effects of future eruptions of Mount St. Helens, and evaluating potential hazards presented by glaciers on other volcanoes.

\section{BACKGROUND}

The majestic cone of Mount St. Helens, which dominates the skyline of the southwestern Washington Cascade Range, has long been famous for its graceful symmetry. Prior to the 1980 volcanism, the mountain was covered with about $5 \mathrm{~km}^{2}$ $\left(1.9 \mathrm{mi}^{2}\right)$ of glacier area, approximately $0.18 \mathrm{~km}^{3}$ $\left(0.043 \mathrm{mi}^{3}\right)$ of snow and ice volume. Wishbone, Loowit, Leschi, Forsyth, Nelson, Ape, Shoestring, Swift, Dryer, Toutle, and Talus Glaciers formed the bulk of the ice cover, which also included a number of perennial snow and ice patches (fig. 1). Seasonal snow with depths from about 3 to $10 \mathrm{~m}$ $(10$ to $33 \mathrm{ft}$ ) mantled the mountain.

Earthquakes began shaking the volcano on March 20, 1980, increasing in frequency until March 26. On March 27, Mount St. Helens broke 130 years of quiescence with a series of minor ash and steam eruptions. A small crater was formed near the summit, a large fracture split the mountain, and a large elliptical region on the north side of the volcano began to bulge at a rate of as much as $2 \mathrm{~m}$ per day. Steam and ash eruptions alternated with intervals of up to 2 weeks of little activity, while the swelling of the mountain's northern flank continued steadily.

On the sunny morning of May 18, 1980, a magnitude-5 earthquake triggered a massive avalanche and eruption, and the northern portion of Mount St. Helens exploded. A horizontal blast devastated the countryside from almost $160^{\circ}$ on the northwest, north, and east sides of the volcano, reaching the Green River Valley $24 \mathrm{~km}(15 \mathrm{mi})$ from the mountain. About $2.8 \mathrm{~km}^{3}$ of the mountain was removed (fig. 2). Blast and avalanche deposits, debris, and pyroclastic flow materials totalling 


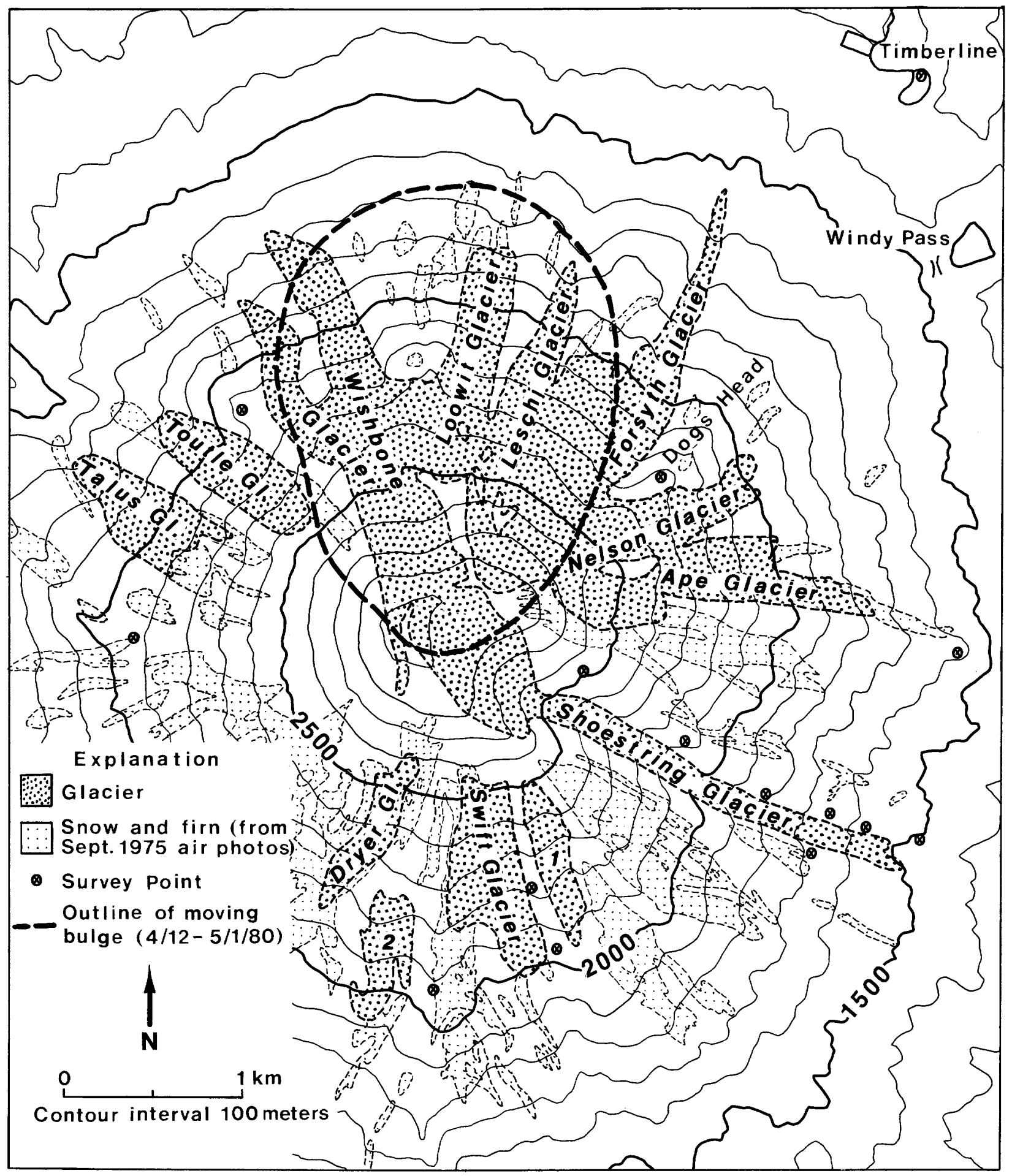

FIGURE 1.-Mount St. Helens before May 18, 1980, showing location of glaciers.

about $2.5 \mathrm{~km}^{3}$ accumulated in the upper North Fork Toutle River valley. Mudflows, lubricated in part by the sudden melting of glaciers and seasonal snow, swept down the North and South Forks of the Toutle River and on down the Cowlitz
River. Similar events occurred in the valleys draining the east flank of the mountain (fig. 3). The eruptive ash clouds reached heights of 20,000 $\mathrm{m}(65,000 \mathrm{ft})$ piercing the troposphere, and dumping several centimeters of ash across eastern 


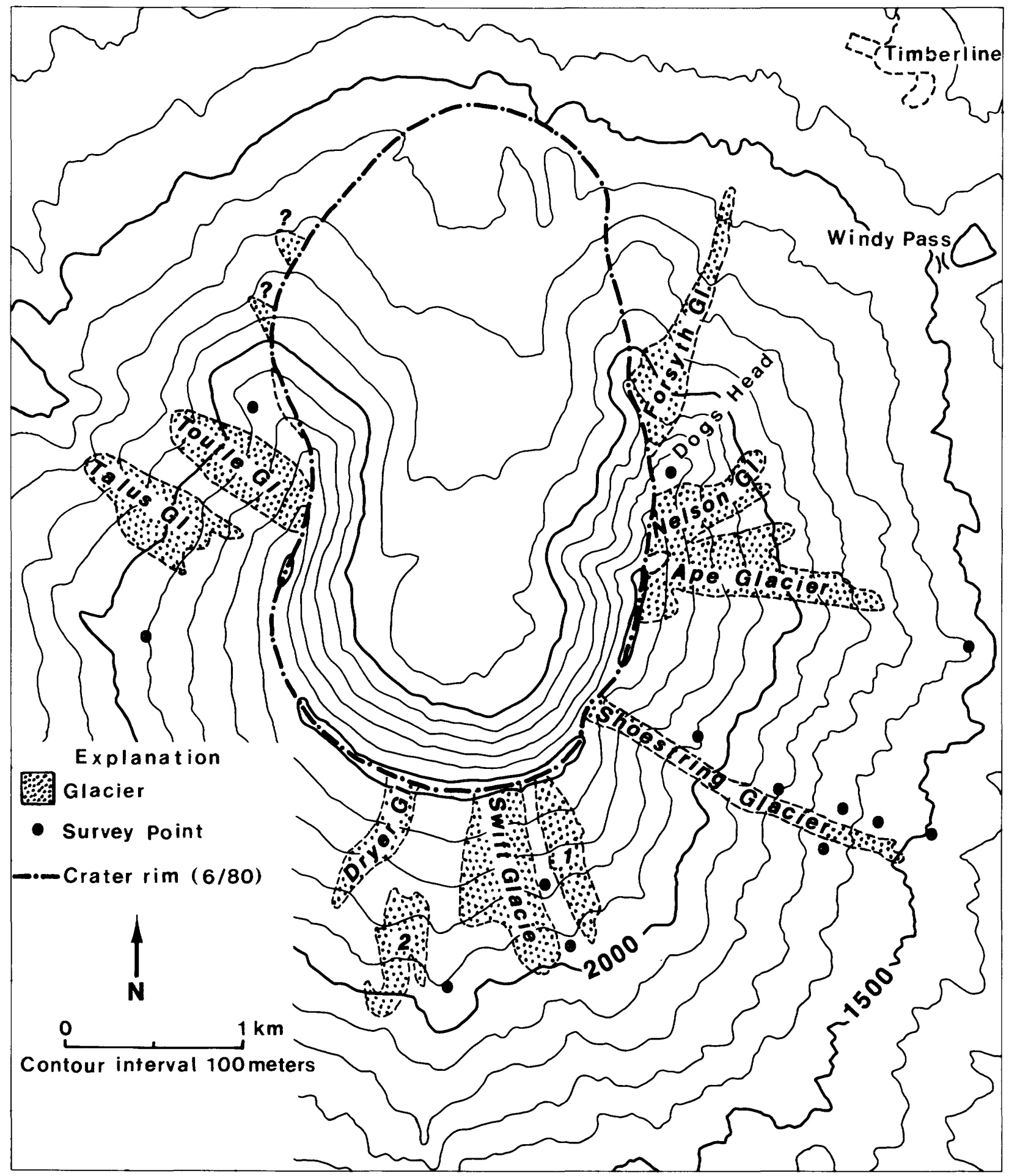

Figure 2.-Mount St. Helens after the May 18, 1980, volcanic blast. The locations of the remains of Wishbone Glacier, covered by debris, is indicated by query.

Washington and parts of Idaho and Montana. A cloud of fine ash encircled the world.

Subsequent eruptions on May 25, June 12, July 22, and August 7 were much smaller in size than that of May 18. Plug domes rose in the main crater and were blown off during later eruptions. With these eruptions, new pyroclastic flows lapped over older flows which covered $7 \mathrm{~km}$ of slope between 


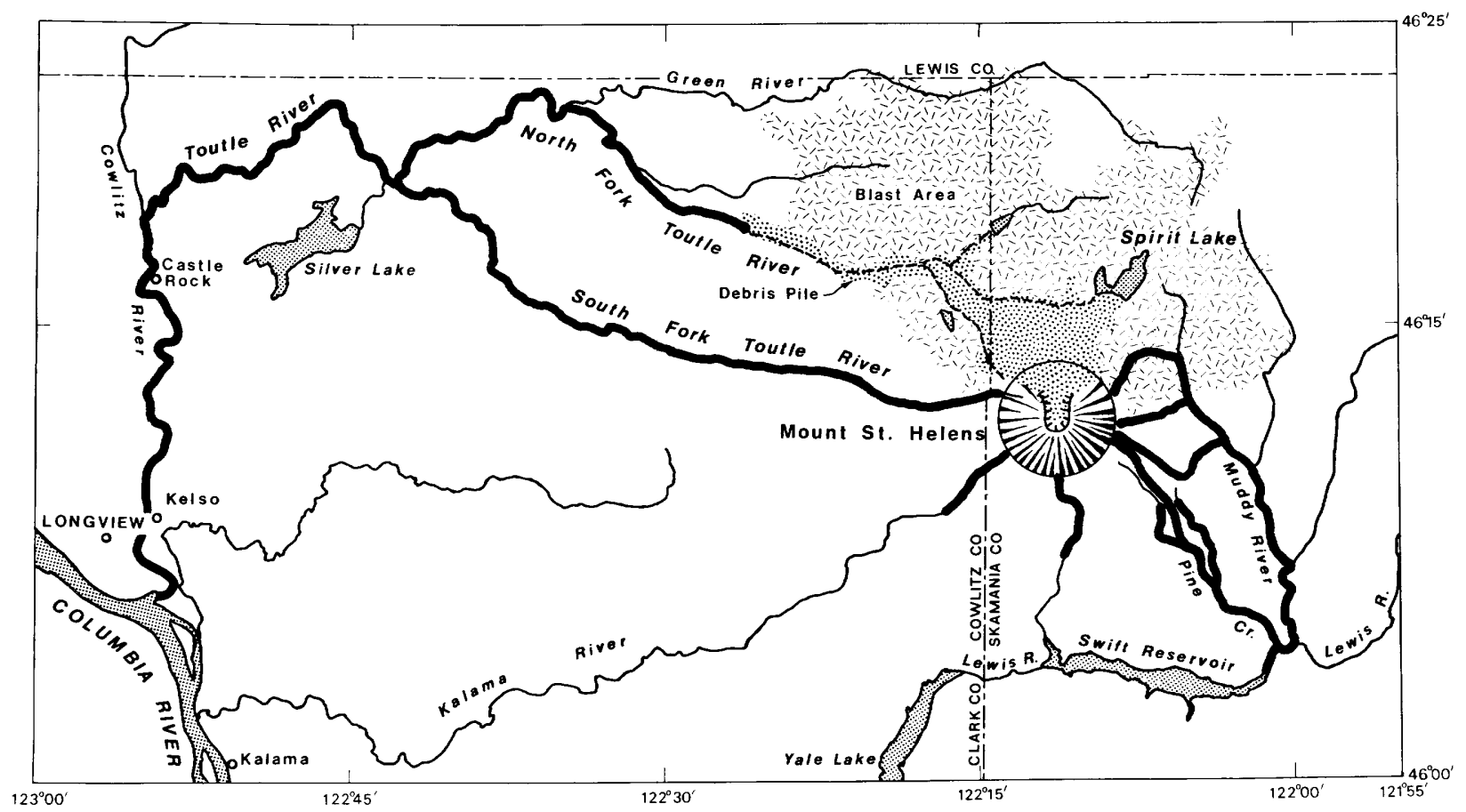

FIGURE 3.-Mount St. Helens area, Washington, showing areas affected by the May 18, 1980, volcanic blast (shutter pattern) and areas covered by volcanic debris (stipple pattern). Heavy lines indicate areas of mudflows and flooding in stream valleys.

the volcano and Spirit Lake (fig. 3). Minor spillovers of hot material fell on the upper slopes of the remaining glaciers during these events, generating mudflows of much smaller volume than those which occurred on May 18.

\section{SPECIFIC EFFECTS OF VOLCANIC ACTIVITY ON GLACIERS}

The eruptions and other types of volcanic activity before, during, and after the cataclysmic May 18 eruption had very different effects on the glaciers. Therefore, discussion of these effects is here divided into three periods: March 20 to May 17, May 18, and May 19 to October 6.

\section{MARCH 20 TO MAY 17}

Growth of the prominent volcanic bulge and continuing earthquakes during this period did not affect terminal positions or flow of the glaciers, except in the immediate vicinity of the growing bulge (fig. 1). Deformation, earthquakes, and oversteepening caused intricate crevassing and ice avalanches on the bulge which affected portions of Forsyth, Loowit, Leschi, Wishbone, Nelson, and upper Shoestring and Toutle Glaciers (fig. 1). Ice velocities measured on lower Shoestring Glacier from February 23 to May 16, 1980, disclosed no major changes from the pre-eruptive velocities of $19 \mathrm{~cm}$ (7.5 in.) per day. Ash layers deposited from March 27 to May 17 around the mountain generally ranged in thickness from a trace to $3 \mathrm{~cm}(1.2$ in.) and were interbedded with snow. Photographs taken before and during this period show the extent of changes which occurred (figs. 4 and 5).

\section{MAY 18}

The explosive eruption of Mount St. Helens on May 18 removed about 70 percent of the ice volume on the volcano (table 1). Large parts of Wishbone, Forsyth, Nelson, Ape, and Shoestring Glaciers and all of Loowit and Leschi Glaciers (figs. 1 and 2) were blasted away, melted, or displaced downvalley as shattered blocks. Some iceblocks were carried by floods and mudflows down the Toutle River valley and many kilometers past the end of the debris pile (fig. 3). About $0.13 \mathrm{~km}^{3}\left(0.032 \mathrm{mi}^{3}\right)$ of ice volume was lost (table 1); much of this was probably melted quickly and contributed to the lubrication of the Toutle River debris and mudflows. Ice fragments pelted survivors on the fringes of the initial blast. Two months later, some blocks of ice still remained buried in the debrisflow deposit on the North Fork Toutle River. 
Forsyth, Nelson, Ape, and Shoestring Glaciers were left beheaded, with their accumulation areas removed (fig. 2).

In addition to the explosive removal of ice, pyroclastic flows melted or eroded snow, firn, and minor amounts of ice from the surface of the remaining glacier ice (table 2). Pyroclastic flows

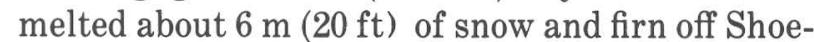
string Glacier, generating large mudflows that swept down the valleys of the Muddy River and Pine Creek. Melting of portions of Nelson and Ape Glaciers caused mudflows which entered Smith Creek. Pine Creek, Muddy River, and Smith Creek mudflows deposited more than 14 million $\mathrm{m}^{3}$ (11,000 acre-feet) of sediment and water in Swift Reservoir soon after the May 18 eruption began.
This volume is about 3 times larger than the estimated surface melt on the parts of Nelson, Ape, and Shoestring Glaciers that remained following the blast, so much of the water must have been derived from melting of the upper removed portions, perhaps combined with melting of seasonal snow. Other large mudflows were generated from ice melted from Toutle and Talus Glaciers. Ash, pumice, and mudflow deposits approximately 1 to $3 \mathrm{~m}$ (3 to $10 \mathrm{ft}$ ) thick covered the remaining glaciers on the volcano (figs. 6, 7, and 8).

The changes in each glacier resulting from the May 18 eruption can be observed by comparing figures 1 and 2 , and are summarized in tables 1 and 2. Ice-volume data reported in these tables required estimates of ice thickness. Many of these

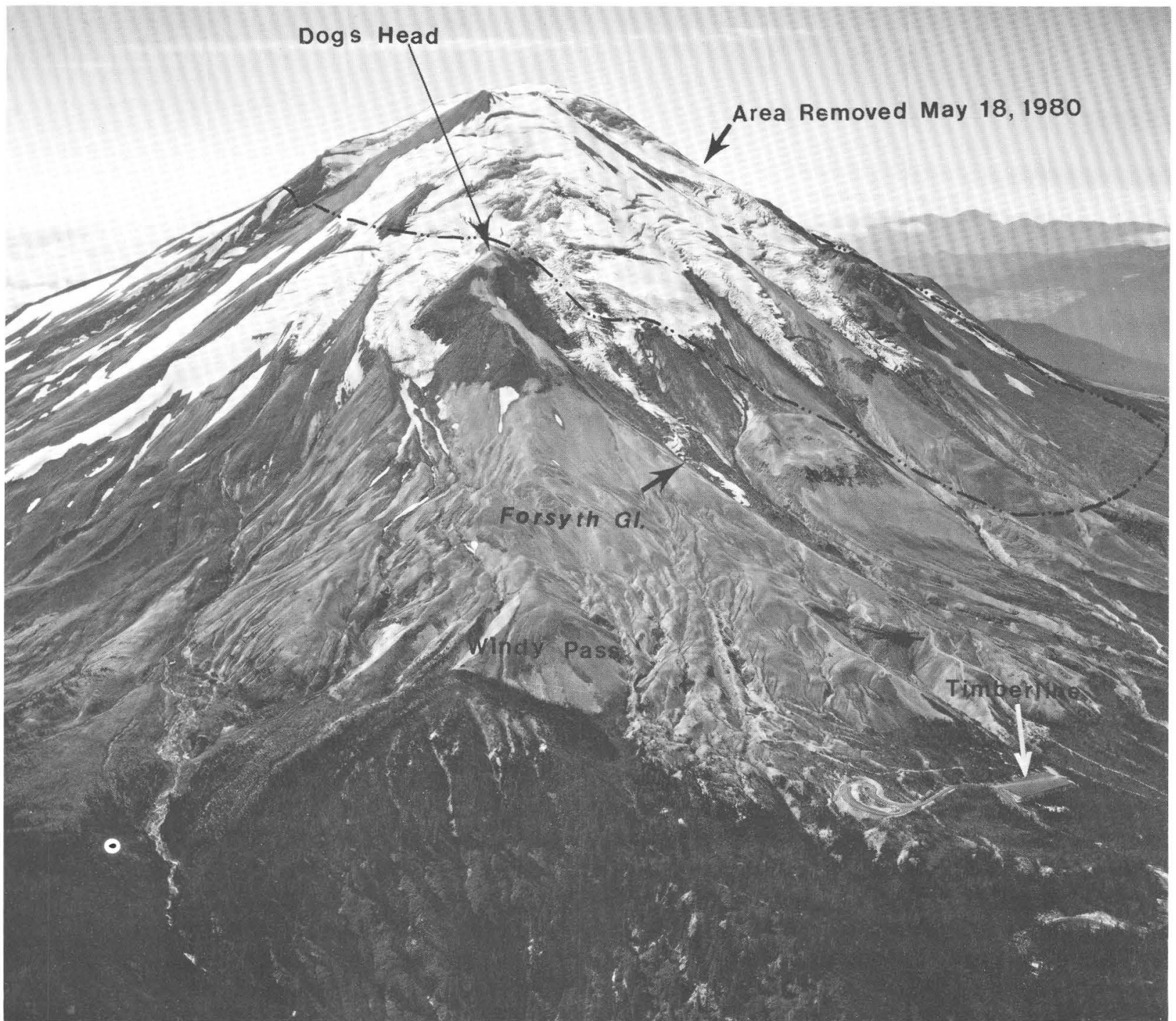

FIGURE 4.-View of Mount St. Helens from the northeast before the 1980 eruptive activity. Dashed line marks boundary of area removed by the May 18, 1980, blast. U.S. Geological Survey photograph 67L7-14, by Austin Post, September $18,1967$. 


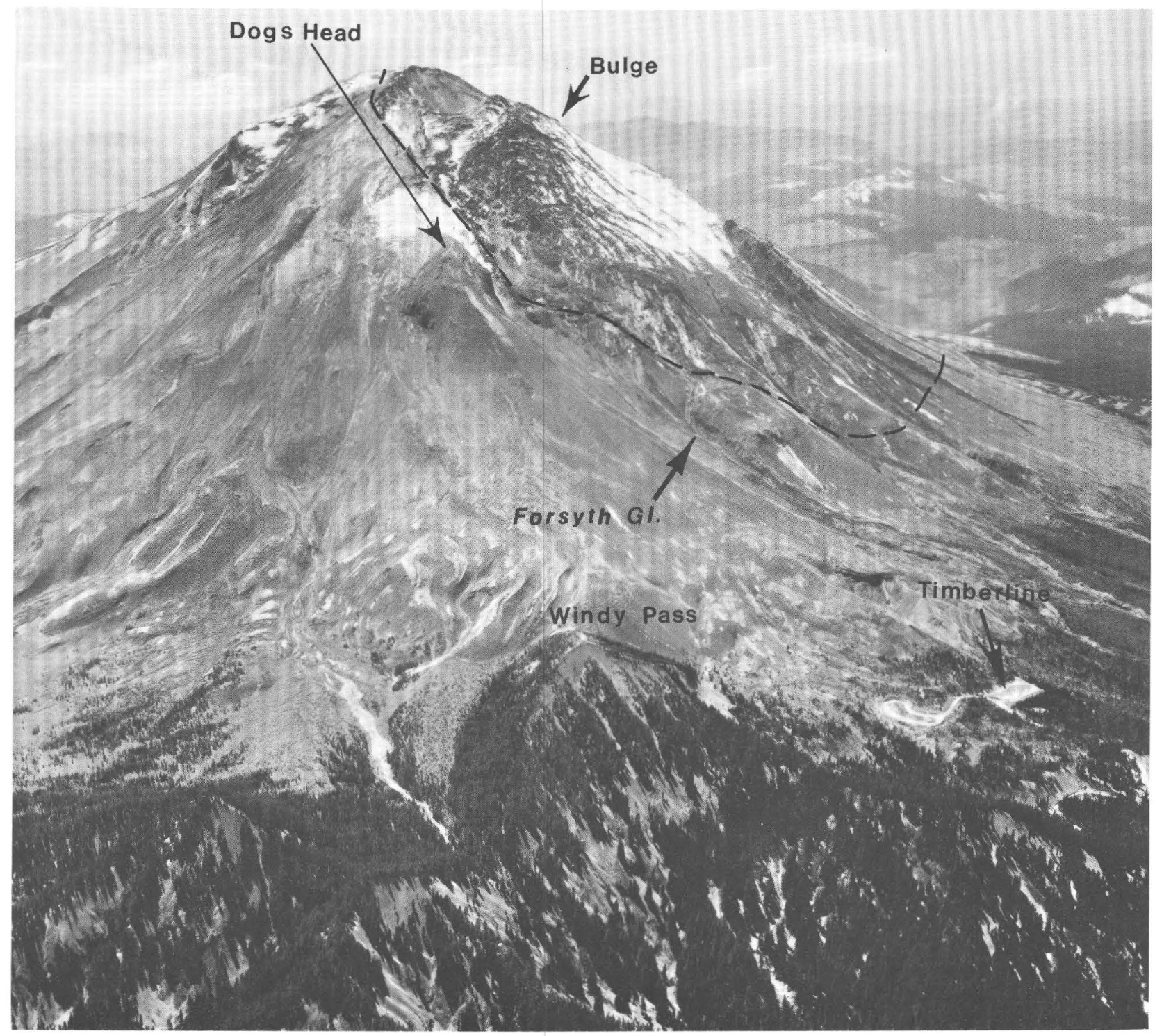

FIGURE 5.-View of Mount St. Helens from the northeast during the period of deformation and minor eruptions preceding the cataclysmic eruption of May 18, 1980. The area of mountain bulging to the north is outlined. Note the extensive crevassing of glaciers on this bulge. Much of the snow and ice is darkened by ash fall. U.S. Geological Survey photograph 80 SZ-140 by David Hirst, May 1, 1980.

estimates were based on comparison with results obtained at other glaciers. Some glacier thickness measurements were obtained during June and July 1979 and 1980 using radio-echo sounding measurements; these are summarized in table 2.

\section{MAY 19 TO OCTOBER 6}

During this period of the Mount St. Helens volcanic activity, deep rills and channels formed on the remaining glaciers and snow patches. These erosional features were the result of small streams cutting into and undermining the insulating ash deposits, commonly eroding through the snow and into the ice below. The rills may have been formed by rainfall on the easily eroded ash deposits. Alternatively, rills may have resulted from the melting of snow and ice owing to heat transfer from pyroclastic flow deposits on portions of the glaciers, some of which were still warm in August 1980 . With the removal of the insulating ash, deep rills quickly developed on the glacier surfaces. Rills are particularly prominent on Toutle and Talus Glaciers (fig. 7).

Following the May 18 eruption, large ice avalanches frequently fell into the crater where the pulverized ice soon melted. The remaining ice cliffs 


\begin{tabular}{|c|c|c|c|c|c|c|c|c|}
\hline \multirow[b]{3}{*}{ Glacier } & \multirow{2}{*}{\multicolumn{3}{|c|}{ AREA }} & \multicolumn{2}{|c|}{ DEPTH } & & & \\
\hline & & & & \multicolumn{2}{|c|}{$\begin{array}{l}\text { Estimated } \\
\text { Average }\end{array}$} & \multicolumn{3}{|c|}{ VOLUME } \\
\hline & $\begin{array}{c}\text { Before } \\
\left(\mathrm{km}^{2}\right)\end{array}$ & $\underset{\left(\mathrm{km}^{2}\right)}{\text { Removed }}$ & $\begin{array}{l}\text { Percent } \\
\text { removed }\end{array}$ & $\begin{array}{l}\text { Before } \\
(\mathrm{m})\end{array}$ & $\begin{array}{l}\text { After } \\
(\mathrm{m})\end{array}$ & $\begin{array}{c}\text { Before } \\
\left(\mathrm{km}^{3}\right)\end{array}$ & $\begin{array}{c}\text { Removed } \\
\left(\mathrm{km}^{3}\right)\end{array}$ & $\begin{array}{r}\text { Percent } \\
\text { removed }\end{array}$ \\
\hline Forsyth & 0.87 & 0.65 & 75 & 45 & 20 & 0.039 & 0.035 & 90 \\
\hline Wishbone - . - - & .83 & .79 & 95 & 45 & 5 & .037 & .037 & 99 \\
\hline Shoestring - - - - & .64 & .43 & 68 & 40 & 30 & .026 & .020 & 77 \\
\hline Ape & .45 & .11 & 24 & 35 & 30 & .016 & .006 & 37 \\
\hline Loowit_-_-_-_- & .43 & .43 & 100 & 30 & 0 & .013 & .013 & 100 \\
\hline Swift $\ldots \ldots$ & .36 & .03 & 7 & 25 & 25 & .009 & .001 & 11 \\
\hline Nelson -- - - - - & .29 & .12 & 41 & 35 & 30 & .010 & .005 & 50 \\
\hline Toutle & .28 & .02 & 4 & 30 & 15 & .008 & .004 & 50 \\
\hline Leschi - - - - - & .26 & .26 & 100 & 30 & 0 & .008 & .008 & 100 \\
\hline Talus_-_...... & .23 & 0 & 0 & 30 & 15 & .007 & .003 & 43 \\
\hline Unnamed (1) - - & .16 & 0 & 0 & 20 & 20 & .003 & 0 & 0 \\
\hline Dryer & .14 & .02 & 14 & 15 & 15 & .002 & 0 & 0 \\
\hline Unnamed (2) - - & .08 & 0 & 0 & 15 & 15 & .001 & 0 & 0 \\
\hline Total _..-- & 5.02 & 2.86 & -- & -- & -- & 0.179 & 0.132 & -- \\
\hline
\end{tabular}

TABLE 2.-Depths of glaciers on Mount St. Helens measured by radio-echo sounding

\begin{tabular}{lcccc}
\hline & $\begin{array}{c}\text { Altitude } \\
(\mathrm{m})\end{array}$ & Date & $\begin{array}{c}\text { Number of } \\
\text { measure- } \\
\text { ments }\end{array}$ & $\begin{array}{c}\text { Average } \\
\text { centerline } \\
\text { depth }(\mathrm{m})^{1}\end{array}$ \\
\hline Shoestring -- & $1630-1880$ & $06 / 08 / 79$ & 14 & 56 \\
& 1560 & $07 / 20 / 80$ & 2 & 29 \\
Forsyth - - - & 1610 & $07 / 20 / 80$ & 2 & 42 \\
Swift - & 1640 & $07 / 20 / 80$ & 1 & 24 \\
\hline
\end{tabular}

' Depths were estimated by comparison with other glaciers and by radio-echo sounding measurements attempted on Shoestring, Forsyth, and Swift Glaciers. Safe working places for radio-echo sounding were limited. Shallow debris-entrained ice, numerous crevasses, and a thick ash cover caused many spurious reflections. Therefore, most of the radio-echo sounding depths are rather ambiguous.

slowly moved away from the crater rim due to glacier flow and melting. The removal of the accumulation areas of glaciers such as Forsyth and Shoestring may result in stagnation and retreat, but the insulating effect of the thick ash and pyroclastic materials will allow some of the remaining ice to persist for several years.

\section{GLACIER OUTBURST FLOODS}

Outburst floods may be caused by the sudden release of water accumulating in crevasses, potholes, or caverns in glaciers. An example observed in August 1980 of such ponding on Shoestring Glacier was a small lake at an altitude of $2,000 \mathrm{~m}$ $(6,550 \mathrm{ft})$ with a volume of approximately $3,500 \mathrm{~m}^{3}$. Volcanic heating similar to that which generates jokulhlaups (outburst floods) in Iceland may occur, but has not yet been documented on Mount St.
Helens. Outburst floods on Shoestring Glacier during the summer of 1980 did not appear to be as large as those during the previous July and August, but they occurred more frequently, generating small mud and rock flows about every 5 to 10 minutes. Some mudflows were initiated by watersaturated ash decoupling from steep snow and ice slopes. The mudflows totaling about $800 \mathrm{~m}^{3}(28,000$ $\mathrm{ft}^{3}$ ) of muddy water, ash, pumice, and rock debris, were about $1 \mathrm{~m}$ deep during rock flow.

By late August through early October 1980, at least one set of mud and rock flows, depths 2 to 3 $\mathrm{m}$ and total volume about $4,800 \mathrm{~m}^{3}\left(170,000 \mathrm{ft}^{3}\right)$, was observed on Shoestring Glacier each day. These travelled at speeds of about $3 \mathrm{~km} / \mathrm{hr}(2$ $\mathrm{mi} / \mathrm{hr}$ ) and carried large amounts of volcanic debris down the headwaters of the Muddy River. Mudflows were also observed coming from other glaciers on the volcano, especially the Toutle, Talus, and Swift Glaciers. These presented hazards throughout the summer in the narrow canyons below these glaciers.

The rate of discharge of the Shoestring Glacier outlet streams during July 1980 was quite similar to that observed during July 1979, when the flow was $0.23 \mathrm{~m}^{3} / \mathrm{sec}\left(8 \mathrm{ft}^{3} / \mathrm{sec}\right)$; in July 1980 , the flow was $0.18 \mathrm{~m}^{3} / \mathrm{sec}\left(6 \mathrm{ft}^{3} / \mathrm{sec}\right)$. Although the area of the glacier was reduced about 70 percent by the May 18 eruption, the stream discharge was reduced only slightly. Perhaps this was because the area removed was at high altitude where less ablation normally occurs. Another possibility is that 
the terminus stream only reflected local melt, while most of the upper glacier melt was discharged as ground water flow or outburst floods. Increased melt due to thin volcanic ash cover and the scouring of surface streams would also increase the runoff from the remaining ice.

Both before and after the eruptions, the Shoestring Glacier outlet streams did not emerge from the end of the glacier, in contrast to most other glaciers. The streams begin above the altitude of $2,000 \mathrm{~m}(6,500 \mathrm{ft})$, and follow the sides of the glacier, joining about $200 \mathrm{~m}(650 \mathrm{ft})$ downvalley from the terminus which lies at the altitude of $1,520 \mathrm{~m}$ $(5,000 \mathrm{ft})$. The bedload in the outlet streams was high before and after the eruption, filling approximately 50 percent of the stream depth. The glaciers on Mount St. Helens typically flow over lahar, pumice, and other volcanic deposits that are highly permeable; thus, most of the glacier melt water becomes ground water flow, except in areas where the streambed is relatively impermeable glacier ice or old lava flows.

\section{ASH BLANKET EFFECTS}

Preliminary results from ash studies by Carolyn Driedger, U.S. Geological Survey, indicate that a trace to $1 \mathrm{~mm}$ (.04 in.) of ash increases the rate of snowmelt by as much as 20 to 30 percent, but an

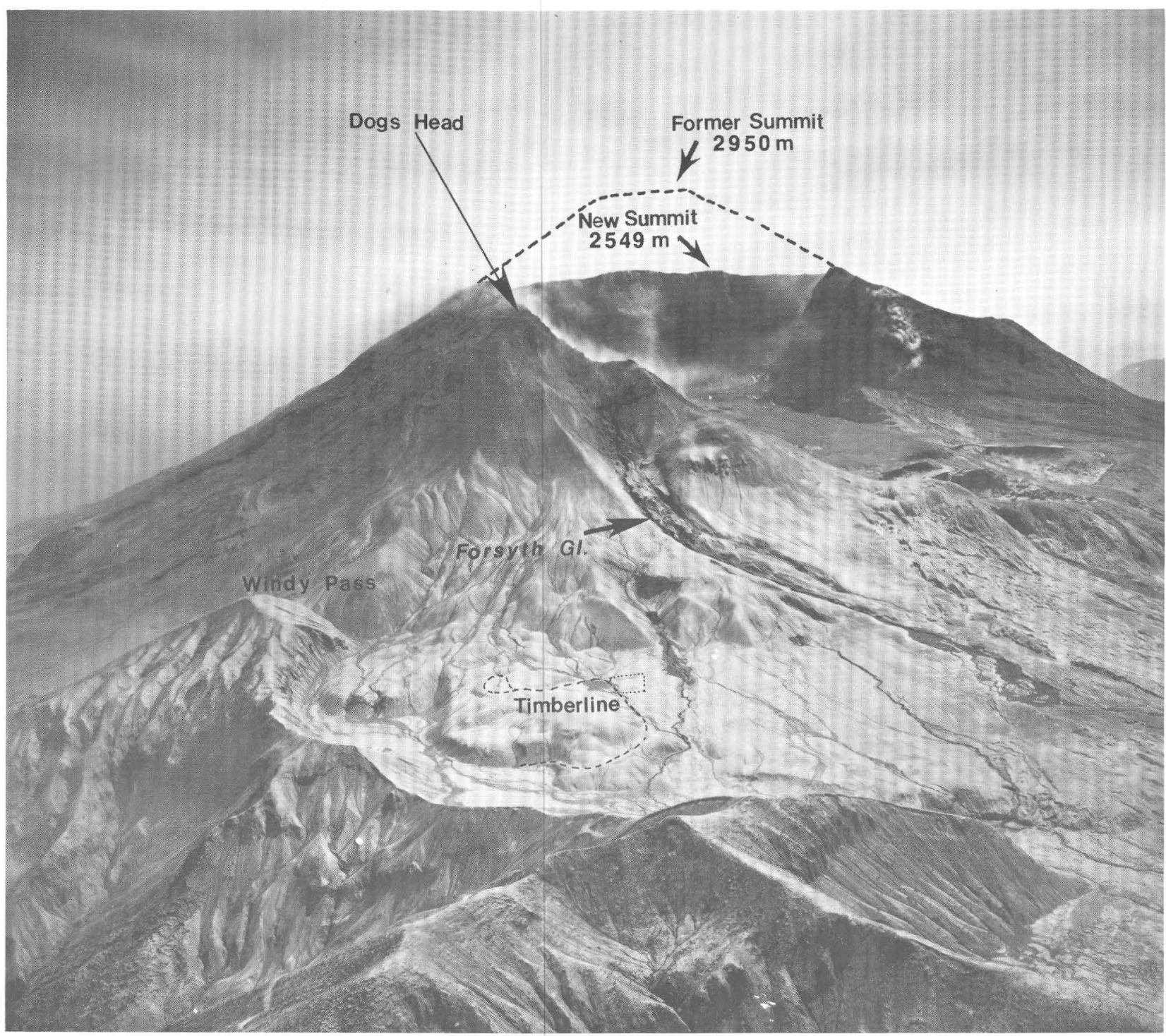

Figure 6.-View of Mount St. Helens from the northeast following the May 18, 1980, eruption. All remaining snow and glacier ice has been covered by ash and other volcanic materials, but the tongue of Forsyth Glacier is clearly discernible below and to the right of Dogs Head. Timberline road and parking areas, deeply buried under ash and debris, are outlined. U.S. Geological Survey photograph 8059-227, by Austin Post, July 24, 1980. 
ash thickness of 10 to $25 \mathrm{~mm}$ (.4 to $1.0 \mathrm{in}$.) or more insulated the snow, reducing melt. Ash depths on the Swift Glacier average 1,300 mm (51 in.). Most of the glaciers remained hidden from view until late summer when crevasses in the snow and ice finally broke through the overlying ash cover; a good example of the difficulty in locating the glaciers is shown in figure 8 . The ash formed a strong insulating blanket; $5 \mathrm{~m}$ (197 in.) of previous winter snow remained on the lower glacier in August 1980. Where deposited on snow or ice, ash deposits thinner than a few centimeters (or about an inch) tended to collect in small clumps. Thin ash distributions over snow and ice became progressively more discontinuous or uneven in thickness with time.

At the ash/snow interface, an unstable, watersaturated layer had developed by July 1980. Snow had recrystallized in the wet equitemperature environment into rounded ice pellets, 1 to $3 \mathrm{~mm}(.04$ to $.12 \mathrm{in}$.) in size under the insulating ash layer. The ice pellets and layers were overlain by about $100 \mathrm{~mm}$ (4 in.) of water-saturated volcanic ash with little or no internal cohesion. During July, above the saturated layer, there was about a meter of relatively dry ash and pumice with deeper deposits in some areas. The ash remained throughout the summer except where deeply gullied by surface streams or removed by minor mudflows. The surface ash generally formed a well-cemented, somewhat impermeable barrier to vertical water transport. In many places, the ash bridged crevasses as they opened in the ice beneath.

By early October 1980, ice grains just beneath thick ash deposits had grown to unusually large sizes of $4 \mathrm{~mm}$ to $10 \mathrm{~mm}(0.2$ to $0.4 \mathrm{in}$.). A layer a few

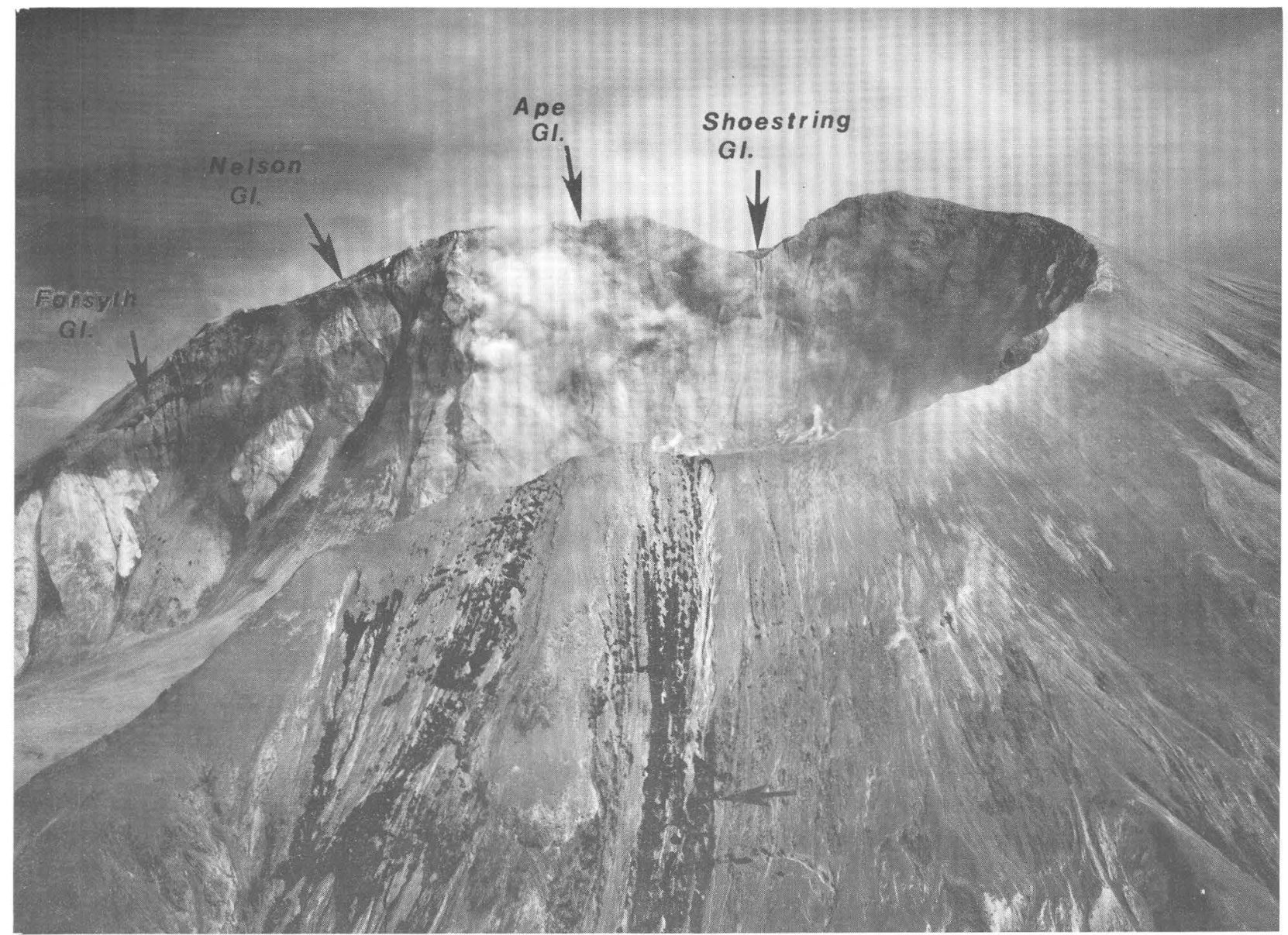

FIGURE 7.-View of crater rim following the May 18 eruption. Arrows above the far rim indicate exposed cross sections (left to right) of Forsyth, Nelson, Ape, and Shoestring Glaciers. The horizontal arrow on the near slope indicates typical rills and channels through ash deposits into Talus Glacier (note crevasse further down the glacier). Dark (wet) streaks to the left indicate the ash-covered Toutle Glacier. U.S. Geological Survey photograph 80S9-115, by Austin Post, July 24, 1980. 


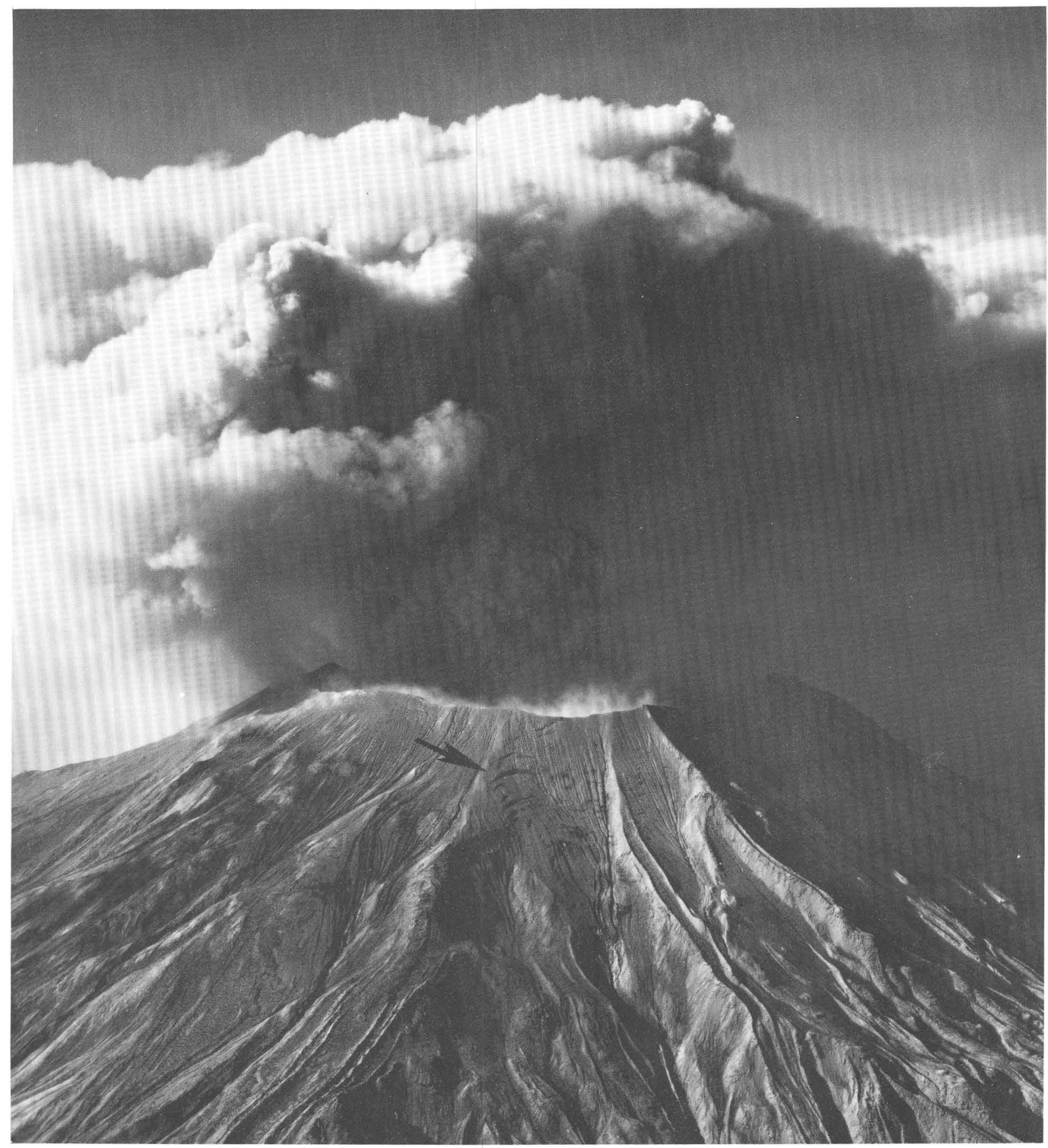

FIgURE 8.-Glaciers on Mount St. Helens following the May 18, 1980, eruption are difficult to detect because of the heavy cover of ash and other volcanic debris. The arrow points to typical glacier crevasses, penetrating through the ash from Swift Glacier on the south side of the mountain. U.S. Geological Survey photograph by Robert Krimmel, 80S9-303, August 7, 1980.

centimeters (about an inch) thick consisting of faceted ice crystals developed as the ice grains grew together during late summer and early fall. The uppermost ice crystals with hexagonal cross sections averaged $10 \mathrm{~mm}$ (.4 in.) in diameter and were very clear.

\section{DISCUSSION: POTENTIAL HAZARDS AND RESEARCH OPPORTUNITIES}

The thick volcanic deposits overlying the glaciers of Mount St. Helens provide a large mass of well-lubricated, unstable debris which may slide 
off the glacier surface, generating mudflows downvalley. Small mudflows occurred throughout the summer of 1980 . In addition, large mudflows could be generated by movement of pyroclastic or lava flows over deep winter snow, firn, or glacier surfaces; the opening of a fumarole under a glacier; or the release of a glacier outburst flood. Recrystallizing ice layers may form unstable zones beneath thick ash deposits, possibly causing slides and mudflows. Glacier outburst floods are potentially damaging. The potential hazard for flooding downvalley will increase in winter months as snow and rime accumulate on the volcano. In particular, Swift and Yale Reservoirs, about $15 \mathrm{~km}(9 \mathrm{mi})$ from the south flank of the volcano, could be subject to large floods and mudflows lubricated by melt water from deep winter snow and glacier ice.

Glaciers on volcanoes may provide precursory information on volcanic activity through evidence of changed patterns of crevasses, velocities, thicknesses, outburst floods, or glacier runoff. Studies on the effects of Mount St. Helens eruptions will greatly aid in the understanding of potential hazards presented by glacier-covered volcanoes such as Mount Hood, Mount Shasta, Mount Rainier, Mount Lassen, Mount Baker, Mount Adams, Glacier Peak, and others.

Research topics of hydrologic or natural-hazard importance can now be addressed on Mount St. Helens. These include understanding the generation of volcanic mudflows and floods, and transient flow dynamics of glaciers with grossly changed geometries and mass balances. In particular, the flow of glaciers over volcanic beds can be modelled more realistically using data from cross sections of glacier beds along the crater rim and along deeply dissected glacier margins. 


